\title{
Effects of Stocking Density on Growth and Production of Silver Barb (Barbonymus gonionotus) in Pond
}

\author{
Baadruzzoha Sarker ${ }^{1}$, Mustafizur Rahman ${ }^{2}$ and Md. Ruhul Amin ${ }^{2}$ \\ ${ }^{1}$ BRAC Fish Hatchery, Sreemongal, Moulvibazar-3210, Bangladesh \\ ${ }^{2}$ Department of Aquaculture, Faculty of Fisheries, Bangladesh Agricultural University, \\ Mymensingh-2202, Bangladesh \\ *Corresponding author and Email: bstushar@gmail.com
}

Received: 11 May 2016

Accepted: 12 December 2016

\begin{abstract}
An experiment was carried out to study the density dependent growth of silver barb (Barbonymus gonionotus) for a period of 2 months during14 March to 18 May, 2013 in ponds with individual water area of 2.0 decimal. The experiment was conducted with three treatments, replicated three times, where stocking densities were 50, 100 and 150 fish/decimal in $T_{1}, T_{2}$ and $T_{3}$, respectively. Feeds were supplied twice daily throughout the study period. Sampling was done at weekly interval throughout the experimental period. Water quality parameters were monitored weekly. Temperature ranged from 26.40 to $30.13^{\circ} \mathrm{C}$, transparency from 32.36 to $46.23 \mathrm{~cm}$, dissolved oxygen from 4.80 to $5.83 \mathrm{mg} / \mathrm{l}$ and $\mathrm{pH}$ from 6.68 to 8.11 . During the study period, growth parameters were analyzed. The mean weight gains were 52.48, 49.98 and $47.87 \mathrm{~g}$, the percent weight gains were 2560.16, 2438.37 and 2335.12, the average daily weight gains were $0.82,0.78$ and $0.74 \mathrm{~g}$, the specific growth rates were 5.12, 5.05 and $4.98 \%$, the survival rates were $89.6,86.67$ and $82.11 \%$ in $\mathrm{T}_{1}, \mathrm{~T}_{2}$, and $\mathrm{T}_{3}$, respectively. There were significant differences among $\mathrm{T}_{1}, \mathrm{~T}_{2}$ and $\mathrm{T}_{3}$ for all the growth parameters. The total productions of silver barb were $603.85,1114.00$ and $1518.06 \mathrm{~kg} / \mathrm{ha} / 2$ months in $\mathrm{T}_{1}, \mathrm{~T}_{2}$ and $\mathrm{T}_{3}$, respectively. The present study indicates that the growth of silver barb was density dependent when grown in monoculture systems and the best stocking density for production was $150 \mathrm{fish} /$ decimal.
\end{abstract}

Keywords: Thai silver barb, Stocking density, Production, Monoculture.

\section{Introduction}

Bangladesh is uniquely rich in water resources. There are two sources of fisheries - inland fisheries and marine fisheries. The inland fisheries again include capture fisheries and culture fisheries. The inland fisheries resources of Bangladesh are considered to be one of the richest in the world which are in the form of rivers, beels, floodplains, ponds, haors, boars, estuaries, brackish water shrimp farms and vast fishing ground of the Bay of Bengal. The inland fisheries resources covers an area of 4700795 ha of which $84 \%$ comprise of natural fisheries and $16 \%$ of closed water culture fisheries, of the inland waters $39,06,434$ ha are open waters 794361 ha (DoF, 2016).

Stocking density is an important parameter in fish culture operations, since it has direct effects on the growth and survival and hence on production. It is an established fact that growth rate progressively increase as the stocking densities decreases and vice-versa. This was because of relatively less number of fish in a pond of similar size could get more space, food 
and dissolved oxygen etc. at the same time. Stocking densities and management measures practiced by pond operators in Bangladesh are not based on scientific knowledge, thus resulting in poor growth and survival of fry. The present study was undertaken to assess the effects of stocking densities on the growth and production of silver barb and the suitable stocking density for culture of the fish in ponds.

\section{Materials and Methods}

\subsection{Study area and time}

The experiment was carried out for a period of 64 days from 14 March to 18 may, 2013 in nine experimental ponds situated at the Field Laboratory Complex, Faculty of Fisheries, Bangladesh Agricultural University, Mymensingh. The ponds were rectangular in shape possessed similar size, depth, basin conformation, contour and bottom type. The surface area of each pond was 2 decimals with an average depth of 1.2 meter. The ponds were free from aquatic vegetation and well exposed to sunlight. All ponds were arbitrarily numbered as pond $1,2,3,4,5,6,7,8$ and 9 for the convenient of study.

\subsection{Pond preparation}

All the experimental ponds were dried and the bottoms were kept exposed for 7 days. Pond dikes were repaired and aquatic weeds were removed manually. Liming was done @ $1.0 \mathrm{~kg}$ per decimal. After 3 days of liming, ponds were filled with underground water from a deep tube well. After filling the ponds with water, cow dungwas used @ 5 kg per decimal to enhance the plankton production.

\subsection{Collection and stocking of fish fingerling}

The fingerlings of silver barb were collected from the stock of Fisheries Field Laboratory Complex under Faculty of Fisheries, Bangladesh Agricultural University. The ponds were stocked with fingerling at three different densities. In $T_{1}$, fingerlings were stocked with 100 individuals /pond and in $\mathrm{T}_{2}$, fingerlings were stocked with 200 individuals /pond. In $T_{3}$, fingerlings were stocked with 300 individuals /pond (Table 1). Before releasing the fingerlings, into the experimental ponds, the initial weight was recorded individually with the help of a portable battery operated balance (Model Hl 400 EX). Prior to releasing the fingerling in the ponds, they were acclimatized with the pond water for half an hour.

\subsection{Selection of feed}

Commercial pellet feeds (Saudi Bangla Fish Feed) was selected for the present experiment. The proximate composition of the experimental feed is given in Table 2.

\subsection{Feeding strategy}

At the beginning of the experiment, feed was supplied at the rate of $15 \%$ body weight of the stocked fish and gradually it was reduced to 14 , 13, 12, 11, 10, 9 and $8 \%$, respectively. The feeding strategy is shown in Table 3. The fish were fed twice daily. Sampling was done regularly at an interval of 7 days.

\subsection{Study on water quality parameters}

Water quality parameters of the experimental ponds were recorded throughout the study period. The water temperature $\left({ }^{\circ} \mathrm{C}\right)$, dissolved oxygen $(\mathrm{mg} / \mathrm{l}), \mathrm{pH}$ and transparency were monitored at weekly basis (Table 4).

\subsection{Harvesting of silver barb}

The fish were harvested on 18th May after 2 months of rearing. Primarily the harvesting of fishes was performed by repeated netting using a berjal (seine net). After harvesting, all fish were counted and weighed individually to assess the survival rate and production.

\subsection{Analysis of experimental data}

Experimental data collected during the whole experimental period were analyzed as follows:

a) Mean weight gain $(\mathrm{g})=$ Mean final weight (g) - Mean initial weight $(\mathrm{g})$

b) Percent weight gain $(\%)=\{($ Mean final weight (g) - Mean initial weight $(\mathrm{g}) /($ Mean initial weight $(\mathrm{g})\} \times 100$ 
c) Average daily weight gain $(\mathrm{g})=$ (Mean final weight $(\mathrm{g})$ - Mean initial weight $(\mathrm{g})) /(\mathrm{T} 2-\mathrm{T} 1)$ Where, $\mathrm{T} 2-\mathrm{T} 1=$ duration of experimental period

d) Specific growth rate (SGR) (\%) = $\frac{\text { logrwz-icysW: }}{I_{2}-T_{1}} \times 100$

Where,

$\mathrm{W}_{1}=$ express as initial body weight $(\mathrm{g})$ of fish

$\mathrm{W}_{2}=$ express as final body weight $(\mathrm{g})$ of fish

$\mathrm{T}_{1}=$ initial time of the experiment
$\mathrm{T}_{2}=$ time at the end of the experiment

e) Survival rate $(\%)=($ No. of fish harvest $) /($ No. of fish stocked) $\times 100$

f) Production $(\mathrm{kg} / \mathrm{dec} / 2$ months)

At the end of the experiments, most of the fishes were caught by net and the rest were caught by dewatering. Production was calculated as:

Production $=$ No. of fish harvested $\times$ Average final weight of fish $(\mathrm{g})$

Table 1. Experimental layout of silver barb culture

\begin{tabular}{lllll}
\hline Treatment & $\begin{array}{l}\text { Replication } \\
\text { (Pond no.) }\end{array}$ & $\begin{array}{l}\text { Pond size } \\
\text { (Dec.) }\end{array}$ & $\begin{array}{l}\text { Stocking } \\
\text { density/pond }\end{array}$ & $\begin{array}{l}\text { Stocking size } \\
\text { (g) }\end{array}$ \\
\hline \multirow{3}{*}{ T-1 } & R-1 (1) & 2 & 100 & 2 \\
& R-2 (2) & 2 & 100 & 2 \\
& R-3 (3) & 2 & 100 & 2 \\
T-2 & R-1 (4) & 2 & 200 & 2 \\
& R-2 (5) & 2 & 200 & 2 \\
T-3 & R-3 (6) & 2 & 200 & 2 \\
& R-1 (7) & 2 & 300 & 2 \\
\hline
\end{tabular}

Table 2. Proximate composition of different types of Saudi Bangla Fish Feeds

\begin{tabular}{lll}
\hline Constituents $(\%)$ & Fursery & Feed type \\
\hline Moisture & 13.68 & Starter-1 \\
Protein & 25.73 & 13.16 \\
Lipid & 8.40 & 26.08 \\
Ash & 22.39 & 8.85 \\
Carbohydrate & 23.60 & 19.97 \\
Fibre & 6.20 & 26.06 \\
\hline
\end{tabular}

Table 3. Feeding strategy for different types of feeds

\begin{tabular}{lcc}
\hline Culture period (days) & Types of supplied feed & Amount of feed (\% body weight) \\
\hline $1-7$ & Nursery & 15 \\
$8-14$ & Nursery & 14 \\
$15-22$ & Nursery & 13 \\
$23-29$ & Nursery & 12 \\
$30-36$ & Starter & 11 \\
$37-43$ & Starter & 10 \\
$44-50$ & Starter & 9 \\
$51-64$ & Starter & 8 \\
\hline
\end{tabular}




\subsection{Statistical analysis}

The data obtained on the growth performance of fish, survival rate and production were statistically analyzed using analysis of variance (ANOVA) with the help of SPSS (Statistical Package for Social Science).

\section{Results and Discussion}

The highest mean weight gain of silver barb was $52.48 \mathrm{~g}$ in $\mathrm{T}_{1}$ with lowest stocking density of $100 /$ pond compared to other $T_{2}$ (200/pond) and $\mathrm{T}_{3}$ (300/pond). The lower stocking density reduces competition among the fishes which influenced them to take feed properly and it might be absent in the treatments with higher stocking densities. The present results coincided with the findings of Alikunhi (2005). In the present study, The SGR (\% per day) was $5.12 \pm 0.05,5.05 \pm 0.02$ and $4.98 \pm 0.02$ in $\mathrm{T}_{1}, \mathrm{~T}_{2}$ and $\mathrm{T}_{3}$, respectively. The SGR (\% per day) of silver barb reported by Talukder et al. (2004) were 2.42 to 2.03 (\%/day) in different treatments. The results observed during the present study were in agreement with the above authors.

Temperature is one of the most important physical factors which influence the growth, reproduction and other biological activities of aquatic organisms specially fish. In the present experiment, the water temperature fluctuated from 26.40 to $30.13^{\circ} \mathrm{C}$ (Table 4). The mean values of water temperature were $28.08 \pm 1.37^{\circ} \mathrm{C}$ in $\mathrm{T}_{1}, 28.40 \pm 1.24^{\circ} \mathrm{C}$ in $\mathrm{T}_{2}$ and $28.38 \pm 1.24^{\circ} \mathrm{C}$ in $\mathrm{T}_{3}$ (Table 5). Ahmed et al (2015) recorded that temperature ranged from 29.25 to $33.5^{\circ} \mathrm{C}$ in the ponds of BAU Campus.

The transparency of water normally indicates the water productivity. Transparency is influenced by the suspended materials and microorganisms. During the experimental period, water transparency ranged from 32.3 to $46.23 \mathrm{~cm}$. The mean value of water transparency of the ponds under $\mathrm{T}_{1}, \mathrm{~T}_{2}$ and $\mathrm{T}_{3}$ were $35.38 \pm 0.89,35.58 \pm 1.27$ and $39.38 \pm 1.33 \mathrm{~cm}$, respectively. Other researchers reported almost similar transparency values of pond water under similar experiments Ahmed et al. (2015) recorded transparency ranging from 28 to $34 \mathrm{~cm}$. In the present experiment, the transparency values were closely near to productive range 35.38 to $39.38 \mathrm{~cm}$.

Dissolved oxygen is the most important factor in fish culture and for better production, optimization of dissolved oxygen is essential. In the present study, dissolved oxygen content recorded was between 4.80 and $5.90 \mathrm{mg} / \mathrm{l}$. The mean values of dissolved oxygen content were $5.24 \pm 0.09$ in $\mathrm{T}_{1}, 5.39 \pm 0.13$ in $\mathrm{T}_{2}$ and $5.3 \pm 0.09$ $\mathrm{mg} / \mathrm{l}$ in $\mathrm{T}_{3}$ (Table 5). Ahmed et al. (2015) found dissolved oxygen 5.9 to $7.2 \mathrm{mg} / \mathrm{l}$ in the research ponds of BAU Campus, Mymensingh. From the above findings, it might be concluded that the oxygen content of the present experimental ponds were within the productive range.

$\mathrm{pH}$ is considered as an important factor in fish culture. It indicates the acidity-alkalinity condition of a water body. It is also called the productivity index of a water body. The circumneutral $\mathrm{pH}$ or slightly alkaline $\mathrm{pH}$ is most suitable for fish culture. During the present experimental period, $\mathrm{pH}$ values were slightly alkaline which indicate good $\mathrm{pH}$ conditions for fish culture. Fluctuations of the $\mathrm{pH}$ values of the experimental ponds ranged from 6.68 to 8.11 . The mean values of $\mathrm{pH}$ were $7.62 \pm 0.19$ in $\mathrm{T} 1$, $7.36 \pm 0.15$ in $\mathrm{T} 2$ and $7.40 \pm 0.12$ in $\mathrm{T}_{3}$, respectively (Table 5). Ahmed et al. (2015) stated that the optimum $\mathrm{pH}$ range for Thai polyculture in pond was 6.9 to 7.45 .

In the present study, the average daily weight gains (ADG) (g) were 2.46, 2.33 and 2.23 in $\mathrm{T}_{1}$, $\mathrm{T}_{2}$ and $\mathrm{T}_{3}$, respectively. Islam (2009) reported that ADG of rohu, catla and mrigal were 0.48 , 0.60 and $0.62 \mathrm{~g}$ which were more or less agreed with the results of the present studying the present study, production of silver barb was found to be $603.85 \mathrm{~kg} / \mathrm{ha} / 2$ months in $\mathrm{T}_{1}$, $1114.00 \mathrm{~kg} / \mathrm{ha} / 2$ months in $\mathrm{T}_{2}$ and 1518.06 $\mathrm{kg} / \mathrm{ha} / 2$ month in $\mathrm{T}_{3}$ (Table 6). Talukder et al. (2004) found 2.76 ton/ha/yr net production of sharpunti where fresh duck weed was 
supplemental feed and the production was significantly higher in ponds with supply of duck weed than without supply of duck weed. In comparison with the findings of the above researchers the production of silver barb in the present study was satisfactory.
In the present study, the survival rate of silver barb in $\mathrm{T}_{1}, \mathrm{~T}_{2}$ and $\mathrm{T}_{3}$ were 89.67, 86.66 and $82.11 \%$, respectively (Table 6). The survival rates were fairly high during the present study which was essential for any good culture practice.

Table 4. Weekly fluctuation of water quality parameters of the pond under different treatments during the study period

\begin{tabular}{|c|c|c|c|c|c|c|c|c|c|c|c|}
\hline \multirow{3}{*}{ Parameters } & \multirow{3}{*}{$\begin{array}{l}\text { Treat- } \\
\text { ments }\end{array}$} & \multicolumn{10}{|c|}{ Sampling date } \\
\hline & & 14 & 21 & 28 & 4 & 11 & 18 & 25 & 2 & 11 & 18 \\
\hline & & March & March & March & April & April & April & April & May & May & May \\
\hline \multirow{3}{*}{$\begin{array}{l}\text { Temperature } \\
\left({ }^{0} \mathrm{C}\right)\end{array}$} & $\mathrm{T}_{1}$ & 26.5 & 26.5 & 27.4 & 28.56 & 29.5 & 30.13 & 28.29 & 28.85 & 29.24 & 28.5 \\
\hline & $\mathrm{T}_{2}$ & 26.91 & 26.4 & 27.76 & 28.63 & 29.8 & 30.02 & 28.78 & 28.71 & 29.53 & 28.8 \\
\hline & $\mathrm{T}_{3}$ & 26.28 & 26.6 & 27.53 & 28.60 & 29.3 & 30.04 & 28.90 & 28.56 & 29.40 & 28.2 \\
\hline \multirow{3}{*}{ DO (mg/l) } & $\mathrm{T}_{1}$ & 5.26 & 4.8 & 5.76 & 5.36 & 5.03 & 5.15 & 5.08 & 5.20 & 5.57 & 5.78 \\
\hline & $\mathrm{T}_{2}$ & 5.83 & 5.0 & 5.53 & 5.73 & 5.12 & 5.9 & 5.20 & 4.81 & 5.43 & 5.61 \\
\hline & $\mathrm{T}_{3}$ & 5.63 & 4.83 & 5.38 & 5.30 & 5.46 & 5.10 & 4.94 & 5.47 & 5.59 & 5.75 \\
\hline \multirow{3}{*}{$\mathrm{PH}$} & $\mathrm{T}_{1}$ & 7.56 & 7.12 & 8.71 & 7.12 & 6.78 & 7.98 & 7.71 & 7.43 & 8.11 & 7.87 \\
\hline & $\mathrm{T}_{2}$ & 7.63 & 6.68 & 7.62 & 7.45 & 7.15 & 7.83 & 7.10 & 6.87 & 7.97 & 7.75 \\
\hline & $\mathrm{T}_{3}$ & 7.46 & 7.04 & 7.36 & 7.26 & 7.05 & 7.8 & 7.02 & 7.60 & 8.07 & 7.68 \\
\hline \multirow{3}{*}{$\begin{array}{l}\text { Transparenc } \\
\mathrm{y}(\mathrm{cm})\end{array}$} & $\mathrm{T}_{1}$ & 39.56 & 34.66 & 39.13 & 43.33 & 32.6 & 35.5 & 37.11 & 32.36 & 33.2 & 31.5 \\
\hline & $\mathrm{T}_{2}$ & 41.4 & 41.33 & 46.23 & 36.66 & 36.70 & 38.2 & 37.05 & 32.89 & 36.8 & 33.45 \\
\hline & $\mathrm{T}_{3}$ & 44.8 & 42.33 & 45.76 & 37.10 & 39.6 & 36.8 & 37.10 & 37.54 & 35.4 & 32.3 \\
\hline
\end{tabular}

Table 5. Average (Mean $\pm \mathrm{SD}$ ) values of water quality parameters under different treatments throughout the study period

\begin{tabular}{llllc}
\hline Treatments & Temperature $\left({ }^{\circ} \mathrm{C}\right)$ & $\begin{array}{l}\text { Dissolved } \\
\text { Oxygen }(\mathrm{mg} / \mathrm{l})\end{array}$ & $\mathrm{P}^{\mathrm{H}}$ & $\begin{array}{c}\text { Transparency } \\
(\mathrm{cm})\end{array}$ \\
\hline $\mathrm{T}_{1}$ & $28.08 \pm 0.46$ & $5.24 \pm 0.09$ & $7.62 \pm 0.19$ & $35.38 \pm 0.89$ \\
$\mathrm{~T}_{2}$ & $28.40 \pm 0.42$ & $5.39 \pm 0.13$ & $7.36 \pm 0.15$ & $35.58 \pm 1.27$ \\
$\mathrm{~T}_{3}$ & $28.38 \pm 0.41$ & $5.3 \pm 0.09$ & $7.40 \pm 0.12$ & $39.38 \pm 1.33$ \\
\hline
\end{tabular}

Table 6. Initial weight (g), stocking density, production ( $\mathrm{kg} / \mathrm{ha} / 2$ months) and survival rate (\%) of Thai sharpunti (Barbonymus gonionotus) in three treatments during the study period

\begin{tabular}{|c|c|c|c|c|c|c|}
\hline \multirow[b]{2}{*}{ Treatments } & \multicolumn{2}{|l|}{ At stocking } & \multicolumn{2}{|c|}{ At harvesting } & \multirow{2}{*}{$\begin{array}{l}\text { Average } \\
\text { survival } \\
\text { rate }(\%)\end{array}$} & \multirow{2}{*}{$\begin{array}{l}\text { Production } \\
\text { (kg/ha / } 2 \\
\text { months) }\end{array}$} \\
\hline & $\begin{array}{l}\text { No. of fish } \\
\text { released }\end{array}$ & $\begin{array}{l}\text { Initial } \\
\text { weight }(\mathrm{g})\end{array}$ & $\begin{array}{l}\text { Final } \\
\text { weight }\end{array}$ & $\begin{array}{l}\text { Fish } \\
\text { harvested }\end{array}$ & & \\
\hline $\mathrm{T}_{1}$ & 300 & 2 & 54.53 & 269 & 89.67 & 603.85 \\
\hline $\mathrm{T}_{2}$ & 600 & 2 & 52.04 & 520 & 86.67 & 1114 \\
\hline $\mathrm{T}_{3}$ & 900 & 2 & 49.90 & 739 & 82.11 & 1518.06 \\
\hline
\end{tabular}




\section{Conclusions}

In the present study, silver barb showed good growth rate in $T_{1}$ than $T_{2}$ and $T_{3}$. The average daily gain (ADG), specific growth rate (SGR), weight gain $(\mathrm{WG})$, among the three treatments were significantly different $(\mathrm{P}<0.01)$. The highest total production was obtained (1518.06 $\mathrm{kg} / \mathrm{ha} / 2$ months) in $\mathrm{T}_{3}$. Thus, the results of the present study clearly show that the fish growth can be increased by low stocking density. But the total production could be increased by higher stocking density. It might be concluded that monoculture of silver barb at a stocking density of $150 /$ decimal can be beneficial for the fish farmers in rural Bangladesh.

\section{References}

Alikunhi, K. H. 2005. Culture of Thai sharpunti polyculture or monoculture has been an economically viable and technically sustainable in perennial water bodies. Indian Journal of Fisheries, 12:124-144.
DoF, 2016. National Fish Week 2016 Compendium, Department of Fisheries, Ministry of Fisheries and Livestock, Bangladesh.

Ahmed, G. U., M. M. Rahman, M. N. Alam and B. Sarker. 2015. Comparative study on growth performance of thai sharpunti (Puntius gonionotus) using two different weeds duck weed (Lemna minor) and azolla fern (Azolla pinneta). Research in Agriculture Livestock and Fisheries, 2(2):369-374.

Islam, S. 2009: Growth performance of carp in ponds fertilized with animal manures, MS Thesis, Department of Aquaculture, Bangladesh Agricultural University.

Talukder, L. L., D. T. Gantt, D. M. Williams and J. H Gholson. 2004. Effect of duckweed (Lemna minor) as dietary fish meal substitute for silver barb (Barbodes gonionotus, Bleeker). Bangladesh Journal of Fisheries Research, 2:35-42. 